\title{
АДМІНІСТРАТИВНО-ПРАВОВИЙ СТАТУС ДЕРЖАВНОГО ІНСПЕКТОРА 3 КОНТРОЛЮ ЗА ВИКОРИСТАННЯМ ТА ОХОРОНОЮ ЗЕМЕЛЬ В УKPAÏHI
}

\author{
БОГДАНОВ Андрій Петрович - здобувач Донецького юридичного інституту \\ МВС України \\ DOI:10.32782/EP.2020.1.5 \\ УДК 342.95: 349.4
}

У статті з урахуванням змісту норм законодавства, що регламентує діяльність державних інспекторів з контролю за використанням та охороною земель, визначено основні риси $i$, як наслідок, сбормульовано поняття адміністративної діяльності державного інспектора 3 контролю за використанням та охороною земель $i$ розкрито $\dddot{\imath}$ правовий зміст иляхом аналізу борм $i$ методів даного виду діяльності. Надана характеристика правового статусу державного інспектора з контролю за використанням та охороною земель як носія державно-владних функиій $і$ повноважень відповідно до чинного законодавства.

Ключові слова: державний інспектор, земля, Держгеккадастр, адміністративно-правовий статус, повноваження, контроль.

Фундаментальним завданням земельної реформи є радикальна зміна ставлення до землі як основного національного багатства. В умовах трансформації земельних відносин, що призвели до збільшення кількості власників землі та землекористувачів, намітилася тенденція до стрімкого зростання кількості правопорушень у галузі земельних відносин, тому особливої уваги набуває питання ефективного здійснення державного контролю за використанням та охороною земель.

Наукове дослідження цієї проблеми сьогодні є надзвичайно актуальним і має важливе теоретичне та практичне значення для регулювання якісно нових земельних відносин. Виконання в повному обсязі завдань щодо здійснення державного контролю у цій сфері стає можливим лише з посиленням ефективної діяльності контролюючих органів, спрямованої на запобігання, своєчасне виявлення i припинення правопорушень. Реалізація завдань та функцій, покладених на державні інспекції як спеціалізовані органи контролю виконавчої влади, повною мірою залежить від ефективної роботи державних інспекторів, однією зі складових якої $є$ адміністративно-юрисдикційна діяльність. Однак практична реалізація адміністративно-юрисдикційної діяльності державного інспектора 3 контролю за використанням та охороною земель сучасним тенденціям відповідає не завжди і не в усьому [1, с. 4].

Найважливішим засобом реалізації державної політики у сфері охорони земельних ресурсів є створення оновленої контролюючої системи органів, спроможної забезпечити ефективний контроль 3 боку суспільства за станом використання та охорони земельних ресурсів країни.

Законодавство розрізняє державний, громадський та самоврядний контроль за використанням та охороною земель. Розмежування між ними, у першу чергу, проводять за суб'єктом здійснення контролю: спеціально уповноважені органи виконавчої влади (державний контроль), місцеві ради (самоврядний контроль), громадськість (громадський контроль). Серед видів контролю за використанням та охоро- 
ною земель особливе місце належить державному контролю.

Етимологічний словник української мови визначає «контроль, контролер, контролювати» як запозичене у XVIII столітті 3 французької мови «controle», що 6 результатом зрощення «contre»- - проти» та «role»- «список», тобто «зворотний, протилежний, подвійний рахунок» [2, с. 338].

Андрійко О. Ф. зазначає, що у визначенні поняття державного контролю слід виходити з того, що це - функція, яку держава здійснює 3 метою перевірки дотримання і виконання поставлених завдань, прийнятих рішень та їх правомірності [3, с. 345]. Разом $з$ тим, контролю притаманні власні функції, основними з яких є:

1) інформаційна функція - дає можливість суб'єкту управління отримати інформацію про стан справ у сфері його інтересів і результати управлінського впливу, відповідність діяльності об'єкта чи об'єктів управління визначеним завданням, встановленим межам;

2) регулююча (коригуюча) функція спрямовується на те, щоб у разі виявлення розходжень між заданими і фактичними діями, шляхами, обраними для досягнення мети, можна було прийняти рішення і спрямувати його на виправлення ситуації;

3) профілактична (превентивна) функція - дає змогу виявити і попередити саму можливість невиконання рішень та скоєння правопорушення або ж припинити дії, що порушують встановлені приписи чи прийняті рішення;

4) правоохоронна функція - спрямована на припинення неправомірних дій, пов'язана 3 притягненням до юридичної відповідальності, застосуванням заходів державного примусу [3, с. 345-346].

Контролю властиві свої принципи, а саме: універсальність (контроль має охоплювати всі ділянки державного, господарського та соціально-культурного будівництва); систематичність (проводиться не одноразово, час від часу, а постійно, за певною схемою); безсторонність (досягається шляхом покладення завдань контролю на осіб, які не зацікавлені в його результатах); реальність (забезпечується наявністю необхідних кваліфікованих кадрів контролерів); дієвість, оперативність, результативність (припускають швидке проведення контрольних дій контролюючим органом у разі одержання повідомлень про порушення, запобігання правопорушенням і причинам, що їм сприяли, своєчасне вжиття заходів щодо їх усунення, притягнення у відповідних випадках винних до відповідальності); гласність (дозволяе, а в деяких випадках і стає обов'язком доведення результатів контролю до відома громадськості або правоохоронних органів, інших осіб, зацікавлених у результатах контролю) [4, с. 241].

Контроль за використанням та охороною земель є однією з важливих функцій державного управління у зазначеній сфері земельних відносин, є різновидом державного контролю $з$ усіма притаманними йому загальними рисами і має свої особливості [5].

Відповідно до ст. 187 Земельного кодексу України, яка визначає завдання контролю у сфері земельних відносин, контроль за використанням та охороною земель полягає в забезпеченні додержання органами державної влади, органами місцевого самоврядування, підприємствами, установами, організаціями і громадянами земельного законодавства України. Варто зауважити, що сфера контролю охоплює всі землі на території України, тобто землі, обмежені їі державними кордонами, незалежно від форми власності на земельні ділянки, їх цільового призначення та організаційних форм господарювання та здійснюється за всіма без винятку суб'єктами земельних відносин, а не тільки за юридичними і фізичними особами [6].

Метою контролю за використанням та охороною земель, що збігається 3 метою всієї екологічної діяльності, є задоволення справедливих соціальних, економічних, екологічних потреб нинішнього і майбутнього поколінь у сфері розвитку й охорони навколишнього природного середовища, а його конкретні цілі визначаються основними формами діяльності у сфері використання й охорони земель, якими є: організація раціонального землекористування; 


\section{Адміністративне право}

охорона земель; забезпечення екологічної безпеки людини [7, с. 192].

Завдання державного контролю за використанням та охороною земель, а також форми і методи його здійснення визначені в Законі України «Про державний контроль за використанням та охороною земель» [8].

Система державного контролю за використанням та охороною земель є складним утворенням і включає низку органів виконавчої влади 3 певною ієрархічною структурою та напрямами контрольної діяльності, а також органи місцевого самоврядування, яким законом делеговано повноваження щодо здійснення державного контролю за використанням та охороною земель [9, с. 10]. Згідно з ч. 1 ст. 188 Земельного кодексу України державний контроль за використанням та охороною земель здійснюється уповноваженими органами виконавчої влади по земельних ресурсах, а за додержанням вимог законодавства про охорону земель - спеціально уповноваженими органами 3 питань екології та природних ресурсів.

Уповноваженим органом виконавчої влади по земельних ресурсах є Державна служба України з питань геодезії, картографії та кадастру. Ї̈ї правовий статус визначається Положенням про Державну службу України з питань геодезії, картографії та кадастру (2015р.) [10]. Згідно 3 цим нормативно-правовим актом Державна служба України з питань геодезії, картографії та кадастру (Держгеокадастр) - центральний орган виконавчої влади, діяльність якого спрямовується і координується Кабінетом Міністрів України через Міністра розвитку економіки, торгівлі та сільського господарства і який реалізує державну політику у сфері топографо-геодезичної і картографічної діяльності, земельних відносин, землеустрою, у сфері Державного земельного кадастру, державного нагляду (контролю) в агропромисловому комплексі в частині дотримання земельного законодавства, використання та охорони земель усіх категорій і форм власності, родючості грунтів.
Усі інспекції залежно від компетенції поділяються на дві групи: 1) ті, що мають повноваження міжвідомчого характеру;2) ті, що не мають таких повноважень, тобто здійснюють свої функції тільки в межах того чи іншого відомства. Інспекції, що мають повноваження міжвідомчого (надвідомчого) характеру, є державними інспекціями та здійснюють свої функції у межах наданої компетенції незалежно від відомчої підпорядкованості об'єктів [11, с. 675].

Характер і зміст компетенції державних інспекцій, як зазначає Н. В. Лебідь, дозволяє визначити їх як самостійні державні органи виконавчої влади надвідомчої компетенції, які здійснюють функції контролю щодо діяльності державних органів, їх посадових осіб, фізичних i юридичних осіб у конкретних галузях народного господарства або в державному управлінні щодо дотримання законності $[12$, c. 65$]$.

Посадові особи Держгеокадастру та його територіальних органів, які є державними інспекторами у сфері державного контролю за використанням та охороною земель і дотриманням вимог законодавства України про охорону земель, у межах своїх повноважень мають право: безперешкодно обстежувати в установленому законодавством порядку земельні ділянки, що перебувають у власності та користуванні юридичних і фізичних осіб, перевіряти документи щодо використання та охорони земель; давати обов'язкові для виконання вказівки (приписи) з питань використання та охорони земель і дотримання вимог законодавства про охорону земель відповідно до їх повноважень, а також про зобов'язання приведення земельної ділянки у попередній стан у випадках, установлених законом, за рахунок особи, яка вчинила відповідне правопорушення, з відшкодуванням завданих власнику земельної ділянки збитків; складати акти перевірок чи протоколи про адміністративні правопорушення у сфері використання та охорони земель і дотримання вимог законодавства про охорону земель та розглядати відповідно до законодавства справи про адміністративні право- 
порушення, а також подавати в установленому законодавством порядку до відповідних органів матеріали перевірок щодо притягнення винних осіб до відповідальності; у разі неможливості встановлення особи порушника земельного законодавства на місці вчинення правопорушення доставляти його до органів Національної поліції чи до приміщення виконавчого органу сільської, селищної, міської ради для встановлення особи порушника та складення протоколу про адміністративне правопорушення; отримувати в установленому законодавством порядку від центральних та місцевих органів виконавчої влади, органів влади Автономної Республіки Крим, органів місцевого самоврядування, підприємств, установ та організацій незалежно від форми власності документи, матеріали та іншу інформацію, необхідну для виконання покладених на Держгеокадастр завдань; проводити лабораторний аналіз стану забруднення земель, у тому числі радіоактивного, в зонах безпосереднього впливу викидів і скидів підприємствами забруднюючих речовин, а також у разі виникнення аварій та надзвичайних ситуацій; звертатися до суду 3 позовом щодо відшкодування втрат сільськогосподарського і лісогосподарського виробництва, а також повернення самовільно зайнятих чи тимчасово зайнятих земельних ділянок, строк користування якими закінчився; викликати громадян, у тому числі посадових осіб, для отримання від них усних або письмових пояснень 3 питань, пов'язаних з порушенням земельного законодавства; передавати до органів прокуратури, органів дізнання та досудового слідства акти перевірок та інші матеріали про діяння, в яких вбачаються ознаки злочину; проводити у випадках, установлених законом, фотографування, звукозапис, кіно- і відеозйомку як допоміжний засіб для запобігання порушенням земельного законодавства [13].

Перша і головна функція державних інспекторів 3 контролю за використанням та охороною земель в Україні - це контроль. Підконтрольними об'єктами при цьому виступають як органи державної влади та органи місцевого самоврядування України, так і фізичні та юридичні особи України, інших країн та особи без громадянства.

Збирання, обробка, аналіз інбормащї, передача ї̈ іншим органам - це друга функція у нашому переліку. Ії можна визначити як інформаційно-аналітичну функцію. Держгеокадастр організовує збирання, зведення та аналіз інформації щодо контролю за використанням та охороною земель, формує відповідну звітність, взаємодіє 3 правоохоронними органами, службами державного контролю, органами місцевого самоврядування, органами виконавчої влади, громадськими формуваннями, а також засобами масової інформації з питань висвітлення актуальних проблем здійснення державного контролю за використанням та охороною земель.

Третьою можна назвати функиію організаиії, яка пов'язана зі створенням організаційного механізму. Iї мета - сформувати керуючі та керовані системи, а також зв'язки й відносини між ними. Так, Держгеокадастр організовує роботу територіальних підрозділів, які діють у складі Республіканського комітету по земельних ресурсах АРК, головних управлінь Держкомзему в областях, містах Києві та Севастополі, районних, міських (міст обласного та районного значення), міжрайонних, міжміських та міськрайонних управлінь (відділів) Держкомзему, старших державних інспекторів цих управлінь (відділів) тощо.

Держгеокадастр має розв'язувати як повсякденні завдання, так і перспективні проблеми. Тому наступною є бункиія прогнозування - передбачення, систематичне дослідження стану, структури, динаміки та перспектив будь-яких явищ і процесів, пов'язаних із здійсненням державного контролю за використанням та охороною земель.

Наступною є функиія планування, адже, тільки визначивши цілі, напрями, завдання, засоби реалізації тих чи інших процесів, можна досягнути конкретної мети. Діяльність Держгеокадастру й його територіальних підрозділів здійснюеться на 


\section{Адміністративне право}

підставі квартальних та річних планів роботи.

Функиія регулювання охоплює переважно поточні заходи щодо будь-яких відхилень від завдань і заданих програм. За допомогою регулювання забезпечується режим оптимальної діяльності Держгеокадастру для утримання керованих процесів у сфері державного контролю за використанням та охороною земель у заданих параметрах.

Координащія - це функція, яка передбачає узгодження дій різних об'єктів 3 метою досягнення певних загальних цілей [14, с. 68].

Аналіз законодавчо закріплених прав державних інспекторів 3 контролю за використанням та охороною земель, а також вивчення їх практичної діяльності дозволяє стверджувати, що ця діяльність складається 3 таких складових частин, як: запобіжна робота; робота зі своєчасного виявлення правопорушень; робота із притягнення винних осіб до адміністративної відповідальності. Тому, на нашу думку, державно-владні повноваження державних інспекторів 3 контролю за використанням та охороною земель доцільно розділити на три групи: 1) повноваження щодо попередження правопорушень;2) повноваження щодо припинення правопорушень; 3) повноваження щодо застосування адміністративних стягнень.

Перша група повноважень відіграє важливу роль у справі забезпечення законності та становить комплекс заходів впливу морального, фізичного, організаційного й іншого характеру, які дають змогу виявляти і не допускати правопорушень у сфері земельних відносин. Вони мають профілактичне спрямування і виражаються, як правило, у вигляді певних обмежень і заборон.

Другою групою повноважень державних інспекторів Держгеокадастру $є$ повноваження щодо припинення правопорушень. Сутність цих повноважень полягає в застосуванні уповноваженими на те органами чи посадовими особами у передбачених законом випадках і в установленому порядку примусовому припиненні пра- вопорушень, що спрямоване на недопущення шкідливих наслідків протиправної поведінки, забезпечення провадження в справах про адміністративні правопорушення, у створенні необхідних умов для можливого в майбутньому притягнення винної особи до адміністративної відповідальності [11, с. 194]. Застосування цих повноважень спричиняється реальною протиправною ситуацією і починається в момент, коли використання повноважень щодо попередження правопорушень стає неефективним. Тобто, тільки тоді, коли відбувається правопорушення, державні інспектори застосовують повноваження щодо припинення правопорушень.

3 моменту припинення правопорушення одним 3 головних завдань є покарання винної особи, для чого треба мати необхідне коло повноважень. Тому mpeтьою групою повноважень державних інспекторів 3 контролю за використанням і охороною земель є повноваження щодо застосування адміністративних стягнень. Адміністративні стягнення застосовуються у процесі спеціальної адміністративноюрисдикційної діяльності, що включає в себе розгляд справ про адміністративні правопорушення, винесення постанов та їх виконання.

Таким чином, державний інспектор 3 контролю за використанням та охороною земель є носієм покладених на Держгеокадастр функцій, головна з яких - це функція контролю. Крім того, функціями, без яких неможлива реалізація головної, визначено: збирання, обробка, аналіз інформації, передача їі іншим органам; функція організації; функція прогнозування; функція планування; функція регулювання; функція координації. Адміністративна діяльність державного інспектора 3 контролю за використанням та охороною земель це врегульована переважно нормами адміністративного права державно-владна, виконавчо-розпорядча, підзаконна діяльність, спрямована на здійснення державного контролю за використанням та охороною земель в Україні. 


\section{Лiтература}

1. Городецька I. А. Адміністративноюрисдикційна діяльність державного інспектора 3 контролю за використанням та охороною земель: дис...канд. юрид. наук: 12.00.07. Київ, 2010. 230 с.

2. Етимологічний словник української мови : у 7 т. / редкол. О. С. Мельничук (головний ред.) та ін. Київ: Наук. думка, 1985. Т. 2. 572 с.

3. Державне управління : проблеми адміністративно-правової теорії та практики / В. Б. Авер'янов, О. Ф. Андрійко, Ю. П. Битяк та ін.; за заг. ред. В. Б. Авер'янова. Київ: Факт, 2003. 384 с.

4. Адміністративне право України: підруч. / Ю. П. Битяк, В. М. Гаращук,О. В. Дьяченко та ін.; за ред. Ю. П. Битяка. Київ: Юрінком Інтер, 2006. 544 с.

5. Кичилюк Т. С. Державний контроль за використанням та охороною земель сільськогосподарського призначення: автореф. дис...канд. юрид. наук: 12.00.07 «Адміністративне право і процес; фінансове право; інформаційне право». Київ, 2007. $19 \mathrm{c}$.

6. Земельний кодекс України: Закон від 25 жовт. 2001 р. № 2768-III. Верховна Рада України. URL: https://zakon.rada.gov. ua/laws/show/2768-14

7. Земельне право України : підруч. / М. В. Шульга (кер. авт. кол.), Г. В. Анісімова, Н. О. Багай та ін.; за ред. М. В. Шульги. Київ: Юрінком Інтер, 2004. 368 с.

8. Про державний контроль за використанням та охороною земель: Закон від 19 черв. 2003 р. № 963-IV. Верховна Рада України. URL: http://zakon.rada.gov.ua/ cgi-bin/laws/main.cgi?nreg=963-15

9. Хом'яченко C. I. Правове забезпечення контролю за використанням та охороною земель в Україні : автореф. дис. на здобуття наук. ступеня канд. юрид. наук: 12.00.06 «Земельне право; аграрне право; екологічне право; природоресурсне право». Київ, 2004. 19 с.

10. Про Державну службу України 3 питань геодезії, картографії та кадастру: постанова Кабінету Міністрів України від 14 січ. 2015 р. № 15. Верховна Рада
Украӥни. URL: https://zakon.rada.gov.ua/ laws/show/15-2015-\%D0\%BF

11. Колпаков В. К., Кузьменко О. В. Адміністративне право України: підруч. Київ: Юрінком Інтер, 2003. 544 с.

12. Аебідь Н. В. Адміністративноправовий статус державних інспекцій в Україні: дис. ... канд. юрид. наук: 12.00.07. Харків, 2004. 202 с.

13. Про Державну службу України 3 питань геодезії, картографії та кадастру: постанова Кабінету Міністрів України від 14 січ. 2015 р. № 15. Верховна Рада україни. URL: https://zakon.rada.gov.ua/ laws/show/15-2015-\%D0\%BF

14. Городецька I. А. Функції Державної інспекції з контролю за використанням та охороною земель. Розвиток наукової думки 2008: зб. матер. Всеукр. наук.-практ. конф. (Миколаїв, 10 жовт. 2008 р.). Миколаїв: НУК, 2008. Т. 3. С. 66-68.

\section{Administrative and legal status of the State Inspector for Land Use and Protec- tion in Ukraine}

The article taking into account the content of the norms of the legislation regulating the activity of state inspectors on control over the use and protection of land, defines the main features and, as a consequence, formulated the concept of administrative activity of the state inspector on control over the use and protection of land and disclosed its legal content by analyzing forms and methods of this activity.

Determining the legal status of the state inspector for control over the use and protection of land as the bearer of state-power functions and powers is of great scientific and practical importance, since the lack of a unified view of scientists regarding the classification of such functions and powers, the fuzzy boundaries between their formulation in the conditions of changing legislation and organizational changes in the functioning of state bodies requires some updating and refinement of existing theoretical views on the issues under consideration.

The State Inspector of Land Use and Protection is the bearer of the functions assigned 


\section{Адміністративне право}

\section{АНОТАЦІЯ}

У статті з урахуванням змісту норм законодавства, шо регламентує діяльність державних інспекторів з контролю за використанням та охороною земель, визначено основні риси $i$, як наслідок, сбормульовано поняття адміністративної діяльності державного інспектора з контролю за використанням та охороною земель $i$ розкрито ї правовий зміст шляхом аналізу борм $i$ методів даного виду діяльності.

Визначення правового статусу державного інспектора з контролю за використанням та охороною земель як носія державно-владних функиій $i$ повноважень має важливе науковопрактичне значення, оскільки відсутність єдиної точки зору науковців щодо класифікацій таких функцій і повноважень, нечіткі межі між їх формулюванням в умовах зміни законодавства й організаційних змін функиіонування державних органів викликає потребу певного оновлення та уточнення існуючих теоретичних поглядів щодо розглядуваної проблематики.

Державний інспектор з контролю за використанням та охороною земель $е$ носієм покладених на Держгеокадастр функиій, головна 3 яких - це функиія контролю. Крім того, бункиіями, без яких неможлива реалізачія головної, визначено: збирання, обробка, аналіз інформачиї, передача ї̈ іншим органам; бункиія організаиій; функиія прогнозування; функиія планування; Функиія регулювання; функиія координаџй. Аналіз законодавчо закріплених прав та вивчення практичної діяльності державних інспекторів 3 контролю за використанням та охороною земель дає підстави виділити три групи їх державно-владних повноважень: повноваження щодо запобігання правопорушенням; повноваження щодо припинення правопорушень; повноваження щодо застосування адміністративних стягнень.

Надана характеристика правового статусу державного інспектора з контролю за використанням та охороною земель як носія державно-владних функиій $i$ повноважень відповідно чинного законодавства. Адміністративна діяльність державного інспектора з контролю за використанням та охороною земель - це врегульована переважно нормами адміністративного права державно-владна, виконавчо-розпорядча, підзаконна діяльність, спрямована на здійснення державного контролю за використанням та охороною земель

Ключові слова: державний інспектор, земля, використання, охорона, адміністративно-правовий статус, повноваження, контроль. to the State Geocadastre, the main one being the control function. In addition, the functions without which the implementation of the main is impossible: collection, processing, analysis of information, transmission to other bodies; function of the organization; forecasting function; planning function; regulation function; coordination function. The analysis of the legislatively enshrined rights and the study of the practical activity of state inspectors on the control over the use and protection of land gives grounds to distinguish three groups of their state-power powers: powers to prevent offenses; powers to terminate offenses; authority to apply administrative penalties.

The description of the legal status of the state inspector for control over the use and protection of land as a carrier of state-power functions and powers according to the current legislation is given. Administrative activity of the state inspector for control over the use and protection of land is mainly regulated by the rules of administrative law state-power, executive-administrative, by-law activity aimed at exercising state control over the use and protection of land.

Keywords: state inspector, land, use, protection, administrative and legal status, powers, control. 